J. Amer. Soc. Hort. Sci. 120(2):254-258. 1995.

\title{
Growth Regulators Delay Foliar Chlorosis of Easter Lily Leaves
}

\author{
Susan S. Han \\ Department of Plant and Soil Sciences, French Hall, University of Massachusetts, Amherst, MA 01003 \\ Additional index words. Lilium longiflorum, chlorophyll, respiration, diffusive resistance, stomata1 closure, senescence, \\ gibberellic acid, benzyladenine

\begin{abstract}
Leaf yellowing of excised Easter lily leaves was significantly delayed by application of gibberellic acids

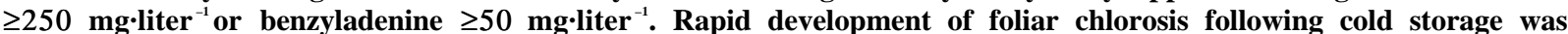
delayed significantly by applying $500 \mathrm{mg}^{\circ} \cdot \mathrm{liter}^{-1}$ of $\mathrm{GA}_{3}$ or $\mathrm{BA}$ before storage. Poststorage treatments were less effective. Development of chlorosis was associated with rapid loss of fresh weight and was not related to the aperture of the stomates (diffusive resistance). Respiration rates of leaves treated with growth regulators were significantly lower than those of the controls.'
\end{abstract}

Foliar chlorosis is considered the primary factor contributing to the loss of postproduction longevity of potted Easter lilies (Staby and Erwin, 1977). Leaf-yellowing symptoms are worse when plants have been cold stored for some time. Longevity of 'Ace' and 'Nellie White' was reduced significantly after storage at 0.5 to $6 \mathrm{C}$ for 1 to 2 weeks (Staby and Erwin, 1977). Seventy percent of 'Nellie White' leaves turned yellow within 3 days after being stored at 2C for 3 weeks (Prince et al., 1987). Application of spermidine, which delays chlorophyll breakdown in some plant species, is ineffective in retarding the development of foliar chlorosis on dark-stored Easter lilies (Prince and Cunningham, 1989). The physiology of the rapid development of foliar chlorosis is not known, but depletion of carbohydrate during storage may be the cause (Miller, 1993).

The effects of growth regulators on leaf senescence vary greatly among plant species. Cytokinins markedly delay or reverse leaf yellowing of some species (Leshem, 1986; Richmond and Lang, 1957; Thimann, 1987). In excised oat leaves, cytokinins retarded the breakdown of chlorophyll and proteins and delayed the onset of rising respiration associated with leaf senescence (Thimann, 1987). Cytokinin applied to yellowing leaves of cocklebur (Xanthium pennsylvanicum L.) reversed the breakdown of aged chloroplasts, resulting in regreening of leaves (Leshem, 1986). The gradual disorganization of grana in the chloroplasts of senescing cocklebur leaves was actually reversed during the regreening process. Gibberellin (GA) is reported to delay leaf senescence of a few species, but the physiological effects of GA on leaf senescence are not clear. Studies on nasturtium (Tropaeolum majus L.) suggested a relationship between the GA, content in leaves and the onset of senescence (Beevers, 1966). Addition of GA, to vase solutions significantly delayed leaf yellowing of Cut Alstromeria (Hicklenton, 1991). In most plant species, however, GA, did not delay leaf senescence, and its content in tissues was not correlated with senescence (Halevy, 1986).

The objectives of this study were to investigate the responses of Easter lily leaves to exogenous GA, and BA and to examine the physiological changes of the leaves in response to the treatments.

Received forpublication 5 July 1994. Accepted for publication 15 Nov. 1994. I thank Gloeckner, for donation of Easter lily bulbs and The Fred C. Gloeckner Foundation, for partially funding this project. The cost of publishing this paper was defrayed in part by the payment of page charges. Under postal regulations, this paper therefore must be hereby marked advertisement solely to indicate this fact.

\section{Materials and Methods}

Plant material. Precooled 'Nellie White' Easter lily bulbs were planted into 1.4-liter (15-cm-diameter) pots filled with commercial peat-lite mix (Fafard Growing Mix No. 2, Conrad Fafard, Springfield, Mass.). Plants were grown in glasshouses at the Univ. of Massachusetts, Amherst, (lat. $42^{\circ} 22.5^{\prime} \mathrm{N}$ ) at $21 \pm 2 / 18 \pm 1 \mathrm{C}$ (day/ night) under natural daylength. Air temperatures were recorded by a datalogger (LI-1000; LI-COR, Lincoln, Neb.) equipped with a thermistor (LI-1000-16; LI-COR). Plants were fertilized with $20 \mathrm{~N}-10 \mathrm{P}_{2} \mathrm{O}_{5}-20 \mathrm{~K}_{2} \mathrm{O}$ at $200 \mathrm{mg} \mathrm{N} /$ liter at every watering.

Excised-leaf experiment. Experiments were conducted with leaf discs or with whole leaves excised at the time when the largest flower bud on the plants reached the white-puffy stage. Only leaves from the middle section of the stems were used in an effort to minimize variations in foliar chlorosis resulting from differences in the position of the leaves on the stem. Growth regulators were applied by briefly dipping leaves in solutions containing various concentrations of gibberellic acid $\left(\mathrm{GA}_{3}\right)$, benzyladenine (BA), or a combination of both. Control leaves were treated in the same manner with distilled water. All solutions contained $0.1 \%$ wetting agent [Tween 20 (polyoxyethylene sorbitan monolaurate)]. After the treatments, surfaces of leaves were allowed to dry in a $20 \mathrm{C}$ room illuminated with $9.5 \mathrm{mmol} \cdot \mathrm{s}^{-1} \cdot \mathrm{m}^{-2}$ cool-white fluorescent lamp. Leaves were then placed individually in scintillation vials containing $-5 \mathrm{ml}$ of distilled water with -0.5 to $1 \mathrm{~cm}$ of the leaf base submersed in the water. Water in the vials was refilled every other day and replaced once a week. Studies were conducted in dark chambers at $20 \pm 1 \mathrm{C}$ and $45 \pm 5 \%$ relative humidity $(\mathrm{RH})$ (Model 818, Precision Scientific, Chicago). The warm and dark conditions were used to hasten the development of foliar chlorosis. Air temperatures and relative humidity in the chambers were measured with a mercury thermometer and a hygrometer, respectively, positioned adjacent to the leaves. For cold-storage experiments, leaves in vials were placed in the dark at $2 \pm 1 \mathrm{C}$ for varying lengths of time before being placed in the dark chambers. Longevity of the leaves was defined as the period from the commencement of the experiment to the day when $\geq 50 \%$ of the leaf area was yellow. Unless otherwise stated, the means 2 standard errors of 10 replicate leaves were reported.

Whole-plant experiments. Whole plants were sprayed, before the 4-week cold storage, with $500 \mathrm{mg} \cdot \mathrm{liter}^{-1}$ of $\mathrm{GA}_{3}$, BA, or water. Following the cold storage, plants were moved to chambers where the percentage of the total number of leaves with a chlorotic area of $\geq 50 \%$ was monitored for 3 weeks. 
Chlorophyll determination. Analysis of chlorophyll, 4 weeks after six replicate excised leaves of each treatment were treated with growth regulators, was by a modification of the procedures of Martin and Thimann (1972). A separate set of untreated leaves was analyzed at the commencement of the experiment to determine initial values. Individual leaves were weighed, rinsed in distilled water, sliced into 2- to-3-mm-wide strips, and extracted in boiling $80 \%$ ethanol for $20 \mathrm{~min}$. Absorbances were read at $665 \mathrm{~nm}$ with a spectrophotometer (model 1201; Spectronic, Rochester, N.Y.). Chlorophyll contents of the treated leaves were expressed as a percentage of the initial values (Martin and Thimann, 1972).

Fresh weight. Water loss, a symptom of leaf senescence, was determined by measuring the loss of fresh weight of leaves over time. Initial fresh weight of each leaf was measured immediately after removal from plants. Leaves were then treated with growth regulators and the fresh weight of each leaf was measured twice a week until the leaves became necrotic. Data were expressed as percent of the initial fresh weight. Additionally, the degree of chlorosis on each leaf was visually estimated, at $10 \%$ increments, as the percentage of leaf area that was yellow at the time of measurement. There were 20 replicate leaves per treatment.

Stomatal closure. Stomatal closure was determined weekly by measuring the diffusive resistance of each leaf with a steady state porometer (LI-1600; LI-COR). The degree of chlorosis on each leaf was rated as in the fresh weight experiment.

Respiration rate. Respiration rate of each leaf, measured 3 days after the growth regulator treatments, was conducted by sealing individual leaves in 470-ml jars wrapped in aluminum foil and placed in 20C chambers for $2 \mathrm{~h}$. One milliliter aliquots of the air were withdrawn, and the $\mathrm{CO}_{2}$ content of the air was determined using a gas chromatograph coupled with a methanizer and fitted with a flame ionization detector (Shimadzu GC-9A, Kyoto, Japan). Respiration rate of the samples was expressed as $\mathrm{mg} \mathrm{CO}_{2} / \mathrm{kg}$ fresh weight per hour.

\section{Results and Discussion}

Postproduction senescence and subsequent removal of lower yellow leaves of Easter lilies results in a section of bare stem, and drastically reduces the aesthetic value of the plants. Chemicals such as phenidone and silver thiosulfate have not been effective in delaying the development of foliar chlorosis of Easter lilies (Prince et al., 1987). Growth regulators have been shown to delay leaf senescence of other plant species (Beevers, 1966; Hicklenton, 1991; Leshem, 1986; Richmond and Lang, 1957; Thimann, 1987). I, therefore, sought to develop a suitable experimental unit for assessing the efficacy of growth regulators on Easter lily leaves. An experimental unit such as leaf discs was tested but concluded not suitable for the study because excessive absorption of growth regulators from the cut surface of leaf discs resulted in the development of necrotic areas, initially along the rim and later spreading throughout the entire disc. Individual excised leaves, on the other hand, were dependable experimental units. The small standard errors demonstrated the uniformity of the senescence in excised leaves (Table 1). In addition, leaves excised from the lowerportion of the plants senesced earlier than those from the upper (data not shown), as would have occurred on intact plants.

Excised leaves in water remained at least $50 \%$ green for an average of 13 days under the conditions tested (Table 1). The longevity of leaves increased with increasing concentrations of $\mathrm{GA}_{3}$. Applications of 50, 250, or $1000 \mathrm{mg} \mathrm{GA}_{3} /$ liter extended the longevity by 5,17 , or 29 days, respectively. In contrast, the increased longevity of leaves treated with BA was not dependent
Table 1. Effects of gibberellic acid and benzyladenine on the longevity of excised leaves from 'Nellie White' Easter lilies. Longevity was defined as the time to $50 \%$ leaf area yellow.

\begin{tabular}{|c|c|c|}
\hline $\begin{array}{l}\text { Growth } \\
\text { regulator }\end{array}$ & $\begin{array}{c}\text { Concn } \\
\left(\mathrm{mg} \cdot \text { liter }^{-1}\right)\end{array}$ & $\begin{array}{c}\text { Longevity }^{2} \\
\text { (days) }\end{array}$ \\
\hline Water (control) & & $13.0 \pm 1.0$ \\
\hline $\mathrm{GA}_{3}$ & 50 & $18.0 \pm 1.3$ \\
\hline $\mathrm{GA}_{3}$ & 250 & $29.5 \pm 1.2$ \\
\hline $\mathrm{GA}^{3}$ & 1000 & $41.7 \pm 1.8$ \\
\hline $\mathrm{BA}^{3}$ & 50 & $31.0 \pm 1.4$ \\
\hline $\mathrm{BA}$ & 250 & $31.1 \pm 1.7$ \\
\hline $\mathrm{BA}$ & 1000 & $29.8 \pm 1.3$ \\
\hline $\mathrm{GA}_{3}+\mathrm{BA}$ & 50 each & $35.6 \pm 1.2$ \\
\hline $\mathrm{GA}_{3}+\mathrm{BA}$ & 250 each & $39.3 \pm 1.9$ \\
\hline $\mathrm{GA}_{3}+\mathrm{BA}$ & 1000 each & $44.2 \pm 0.9$ \\
\hline \multicolumn{3}{|l|}{ Contrast } \\
\hline $\mathrm{GA}_{3}$ vs. $\mathrm{GA}_{3}+\mathrm{BA}$ & & $* * *$ \\
\hline BA vs. $\mathrm{GA}_{3}+\mathrm{BA}$ & & $* * *$ \\
\hline $\mathrm{GA}_{3}$, linear & & $* * *$ \\
\hline $\mathrm{GA}_{3}$, quadratic & & $* * *$ \\
\hline BA, linear & & NS \\
\hline BA, quadratic & & NS \\
\hline $\mathrm{GA}_{3} \pm \mathrm{BA}$, linear & & $* * *$ \\
\hline $\mathrm{GA}_{3} \pm \mathrm{BA}$, quadratic & & NS \\
\hline
\end{tabular}

${ }^{\mathrm{z}} \mathrm{Study}$ was conducted in 20C, dark growth chambers. Data are means SE of 10 replicate leaves.

${ }^{\text {ss }}, *, * *, * * *$ Nonsignificant or significant at $0.01<P \leq 0.05,0.001 \leq P \leq 0.01$, or $P \leq 0.001$, respectively. Polynomial coefficients used in the orthogonal contrasts have been corrected for the unequal spacing between treatments levels.

Table 2. Chlorophyll contents of excised Easter lily leaves 4 weeks after growth regulator treatment.

\begin{tabular}{|c|c|c|}
\hline $\begin{array}{l}\text { Growth } \\
\text { regulator }\end{array}$ & $\begin{array}{c}\text { Concn } \\
\left(\mathrm{mg} \cdot \text { liter }^{-1}\right)\end{array}$ & $\begin{array}{l}\text { Chlorophyll content } \\
\text { (\% of initials) }\end{array}$ \\
\hline Water (control) & & $33.0 \pm 1.5$ \\
\hline $\mathrm{G} \mathrm{A}_{3}$ & 50 & $33.0 \pm 4.5$ \\
\hline $\mathrm{GA}_{3}$ & 250 & $45.3 \pm 2.5$ \\
\hline $\mathrm{G} \mathrm{A}_{3}$ & 1000 & $64.6 \pm 2.0$ \\
\hline $\mathrm{BA}^{3}$ & 50 & $47.2 \pm 10.3$ \\
\hline BA & 250 & $40.2 \pm 3.8$ \\
\hline BA & 1000 & $49.5 \pm 3.7$ \\
\hline $\mathrm{GA}_{3}+\mathrm{BA}$ & 50 each & $48.0 \pm 5.7$ \\
\hline $\mathrm{GA}_{3}+\mathrm{BA}$ & 250 each & $62.7 \pm 4.3$ \\
\hline $\mathrm{GA}_{3}+\mathrm{BA}$ & 1000 each & $70.1 \pm 4.5$ \\
\hline \multicolumn{3}{|l|}{ Orthogonal contrast } \\
\hline $\mathrm{G} \mathrm{A}_{3}$, linear & & $* *$ \\
\hline $\mathrm{GA}_{3}$, quadratic & & NS \\
\hline BA, linear & & NS \\
\hline BA, quadratic & & NS \\
\hline $\mathrm{GA}_{3}+\mathrm{BA}$, linear & & $* *$ \\
\hline $\mathrm{GA}_{3}+\mathrm{BA}$, quadratic & & NS \\
\hline
\end{tabular}

${ }^{2}$ Excised leaves were placed in vials housed in $20 \pm 1 \mathrm{C}$, dark chambers. Data are means \pm SE for three measurements.

Ns, $*, * *, * * *$ Nonsignificant or significant at $0.01<P \leq 0.05,0.001<P \leq 0.01$, or $P \leq 0.001$, respectively. Polynomial coefficients used in the contrasts have been corrected for the unequal spacing between treatments levels.

on the concentrations of BA. All BA-treated leaves remained green about 18 days longer than the untreated leaves. Combinations of GA, and BA at various concentrations also significantly delayed leaf senescence. 
Table 3. Effects of repeated applications, at l-week intervals, of 250 $\mathrm{mg} \cdot$ liter $^{-1}$ gibberellic acid, benzyladenine, or both on longevity of excised 'Nellie White' Easter lilies

\begin{tabular}{lccc}
\hline & \multicolumn{3}{c}{ Longevity (days) } \\
\cline { 2 - 4 } Application & $\mathrm{G} \mathrm{A}_{3}$ & $\mathrm{~B} \mathrm{~A}$ & $\mathrm{GA}_{3}+\mathrm{BA}$ \\
\hline 0 (control) & $12.5 \pm 0.7$ & $12.5 \pm 0.7$ & $12.5 \pm 0.7$ \\
1 & $29.5 \pm 1.2$ & $31.1 \pm 1.7$ & $39.3 \pm 1.9$ \\
2 & $38.7 \pm 4.4$ & $26.5 \pm 1.2$ & $44.6 \pm 0.6$ \\
3 & $43.4 \pm 1.7$ & $27.7 \pm 1.8$ & $41.5 \pm 4.9$ \\
Planned comparison & $* * *$ & $* * *$ & $* * *$ \\
0 vs. 1 & $* * *$ & $*$ & $*$ \\
1 vs. 2 & $\mathrm{~N} \mathrm{~S}$ & $\mathrm{NS}$ & $\mathrm{NS}$ \\
2 vs. 3 & &
\end{tabular}

${ }^{\mathrm{z}}$ Longevity of the leaves was defined as the period from the commencement of the experiment to the day when $50 \%$ of the leaf area was chlorotic. Study was conducted in $20 \pm 1 \mathrm{C}$, dark growth chambers. Data are means \pm SE of 10 replicates.

NS*,**,***Single degree of freedom orthogonal contrast not significant or significant at $0.01<P \leq 0.05,0.001 \leq P 0.01$, and $P \leq 0.001$, respectively.

Table 4. Longevity of excised leaves of 'Nellie White' Easter lilies following 0,2 , or 4 weeks of storage at $2 \mathrm{C}$ with growth regulators applied before or after the storage.

\begin{tabular}{lcc}
\hline \hline $\begin{array}{l}\text { Storage } \\
\text { (week) }\end{array}$ & $\begin{array}{c}\text { Growth } \\
\text { regulation }\end{array}$ & $\begin{array}{c}\text { Longevity }^{\mathrm{y}} \\
\text { (days) }\end{array}$ \\
\hline 0 & Water (control) & $11.5 \pm 0.4 \mathrm{~d}^{\mathrm{x}}$ \\
2 & Water & $6.2 \pm 0.8 \mathrm{e}$ \\
4 & Water & $4.5 \pm 0.6 \mathrm{e}$ \\
0 & $\mathrm{G} \mathrm{A}_{3}$ & $30.6 \pm 2.0 \mathrm{~b}$ \\
2 & $\mathrm{G} \mathrm{A}_{3}$ before & $36.8 \pm 2.2 \mathrm{a}$ \\
4 & $\mathrm{G} \mathrm{A}_{3}$ before & $39.5 \pm 1.5 \mathrm{a}$ \\
2 & $\mathrm{G} \mathrm{A}_{3}$ after & $28.4 \pm 2.1 \mathrm{~b}$ \\
4 & $\mathrm{G} \mathrm{A}_{3}$ after & $13.8 \pm 2.6 \mathrm{~d}$ \\
0 & $\mathrm{~B} \mathrm{~A}_{2}$ & $30.0 \pm 1.7 \mathrm{~b}$ \\
4 & $\mathrm{BA} \mathrm{before}$ & $26.5 \pm 1.9 \mathrm{~b}$ \\
2 & $\mathrm{BA}$ before & $20.2 \pm 2.2 \mathrm{c}$ \\
4 & $\mathrm{BA}$ after & $25.7 \pm 1.3 \mathrm{~b}$ \\
\hline
\end{tabular}

${ }^{2} \mathrm{G} \mathrm{A}_{3}$ or BA at $500 \mathrm{mg} \cdot$ liter $^{-1}$ applied before or after the cold storage. 'Longevity of the leaves was defined as the period from the commencement of the experiment to the day when $50 \%$ of the leaf area was chlorotic. Experiment was conducted in $20 \pm 1 \mathrm{C}$, dark growth chambers. Data are means \pm SE of 10 replicate leaves.

"Mean separation in columns by $\mathrm{LSD}_{0.05}$

The delay in senescence of excised leaves following treatment with $\mathrm{GA}_{3}$ and/or $\mathrm{BA}$ is further evidenced by the retention of chlorophyll (Table 2). As concentrations of $\mathrm{GA}_{3}$ or $\mathrm{GA}_{3}+\mathrm{BA}$ increased, chlorophyll decreased to a lesser extent. In comparison, the breakdown of chlorophyll was not dependent on the concentrations of BA. This data indicates that visual criteria used in the determination of longevity yields similar trends as those from chlorophyll extractions (Table 1 and 2). Results of all subsequent experiments were based on subjective criteria.

The use of repeated applications of the growth regulators was tested in an effort to determine if this extended the longevity of leaves further (Table 3). The incremental effectiveness of growth regulators diminished with increasing numbers of applications. One application of $\mathrm{GA}_{3}, \mathrm{BA}$, or a combination of both significantly increased the longevity of leaves. The second application further delayed chlorosis on leaves treated with $\mathrm{GA}_{3}$ or $\mathrm{GA}_{3}+\mathrm{BA}$, but resulted in a slight reduction in longevity of leaves treated with BA. No differences occurred between leaves treated two or three times, regardless of the growth regulators used.

In another experiment, the effects of cold storage on the senescence of excised leaves were assessed. Longevity of excised leaves decreased significantly as duration of cold storage increased (Table 4). Without cold storage, the longevity of watertreated leaves was 11.5 days compared to the 6.2 and 4.5 days with 2 and 4 weeks of cold storage, respectively. This effect of cold storage on foliar chlorosis was found to be comparable to results of Prince et al. (1987) in which the percentage of chlorotic leaves on intact plants increased linearly with increasing time of storage in the cooler. Foliar application of $0.2 \mathrm{~mm}$ silver thiosulfate (Prince et al., 1987) or $10 \mathrm{~mm}$ spermidine (Prince and Cunningham, 1989) did not prevent the poststorage development of foliar chlorosis. Application of $500 \mathrm{mg} \cdot \mathrm{liter}^{-1} \mathrm{GA}_{3}$ or $\mathrm{BA}$ on excised leaves, in general, retarded the development of foliar chlorosis (Table 4). Leaves treated with $\mathrm{GA}_{3}$ or $\mathrm{BA}$ that were stored for 2 weeks

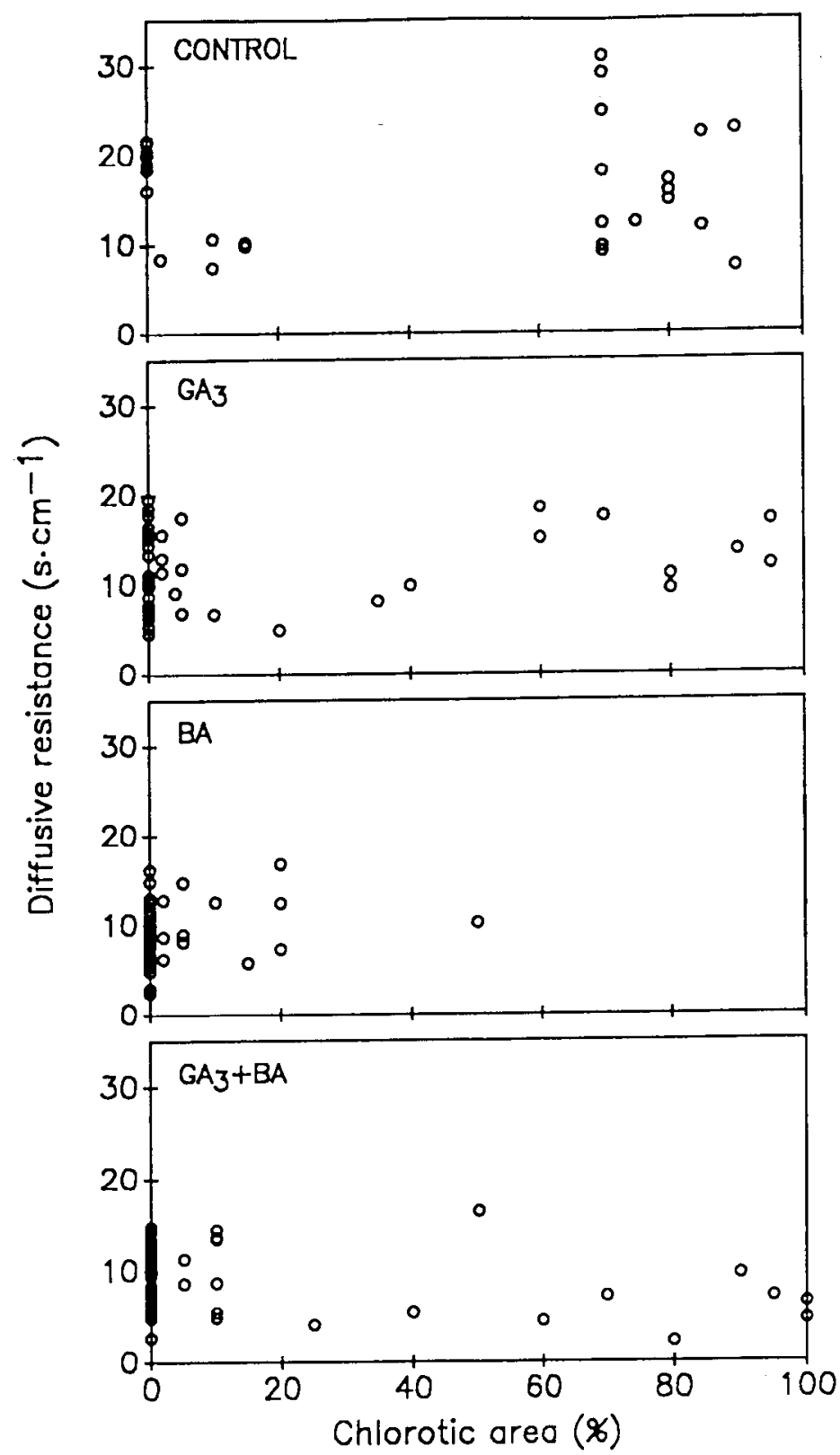

Fig. 1. Relationships between diffusive resistance and foliar chlorosis of excised leaves of Easter lilies. Each datum is a measurement. 


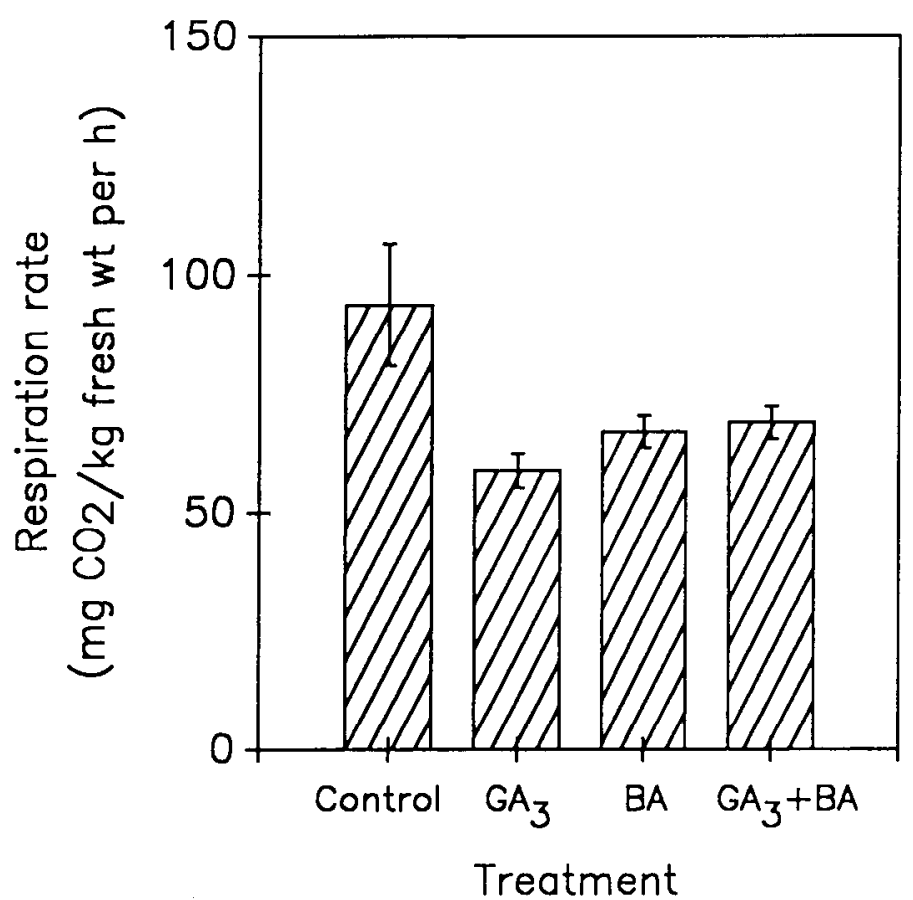

Fig. 2. Respiration rates of excised Easter lily leaves treated with distilled water (control) or $500 \mathrm{mg} \cdot \mathrm{liter}^{-1}$ of $\mathrm{GA}_{3}$, BA, or $500 \mathrm{mg} \cdot \mathrm{liter}^{-1}$ each of $\mathrm{GA}_{3}$ and BA. Measurements were taken after 3 days at $20 \mathrm{C}$ following treatments. Data are means $\pm \mathrm{SE}$ of six replicate leaves.

remained green significantly longer than the controls, regardless of the timing of application. The advantageous effects of growth regulators on foliar chlorosis diminished with a 4-week storage period. Longevity of leaves stored for 4-weeks and treated with BA after the storage were not significantly different from those of the controls. In comparison, $\mathrm{GA}_{3}$ applied either before or after the 4week storage, retarded the development of chlorosis, but the effect was significantly greater when treated before storage. This study indicates that prestorage treatment of excised Easter lily leaves with growth regulators significantly delayed the onset of chlorosis. The rapid development of chlorosis on the cold-stored excised leaves treated with water indicates that senescence probably initiated during storage. Furthermore, data from growth regulators applied after the cold storage suggest that $\mathrm{GA}_{3}$, but not BA, may reverse or slow down the development of chlorosis once the process has been initiated. Regreening of cocklebur leaves treated with cytokinin has been observed and was apparently due to the reversibility of the grana from the disorganized form back to the orderly pattern (Leshem, 1986). Microscopy studies are needed to help determine if application of $\mathrm{GA}_{3}$ improves the longevity of cold-stored excised leaves by reversing, stopping, or delaying the disorganization process in the chloroplasts.

Fresh weight of leaves initially increased slightly and then declined rapidly as the leaves turned yellow (data not shown). The rapid loss of fresh weight associated with senescence of watertreated leaves was delayed on leaves treated with growth regulators. Regardless of treatments, the development of chlorosis was associated with a rapid loss of fresh weight.

The striking correlation between stomatal closure and senescence of oat leaves led to the conclusion that rapid senescence of leaves in the dark is a nonchemical phenomenon and is exerted via the stomatal aperture (Thimann, 1987). Artificial closure of the stomata by phenylmercuric salts, Vaseline, silicone oil, abscisic acid, methyl jasmonate, or darkness stimulated rapid senescence of oat leaves. In oat leaves treated with cytokinin or fusicoccin, on the other hand, stomates remained open and senescence was

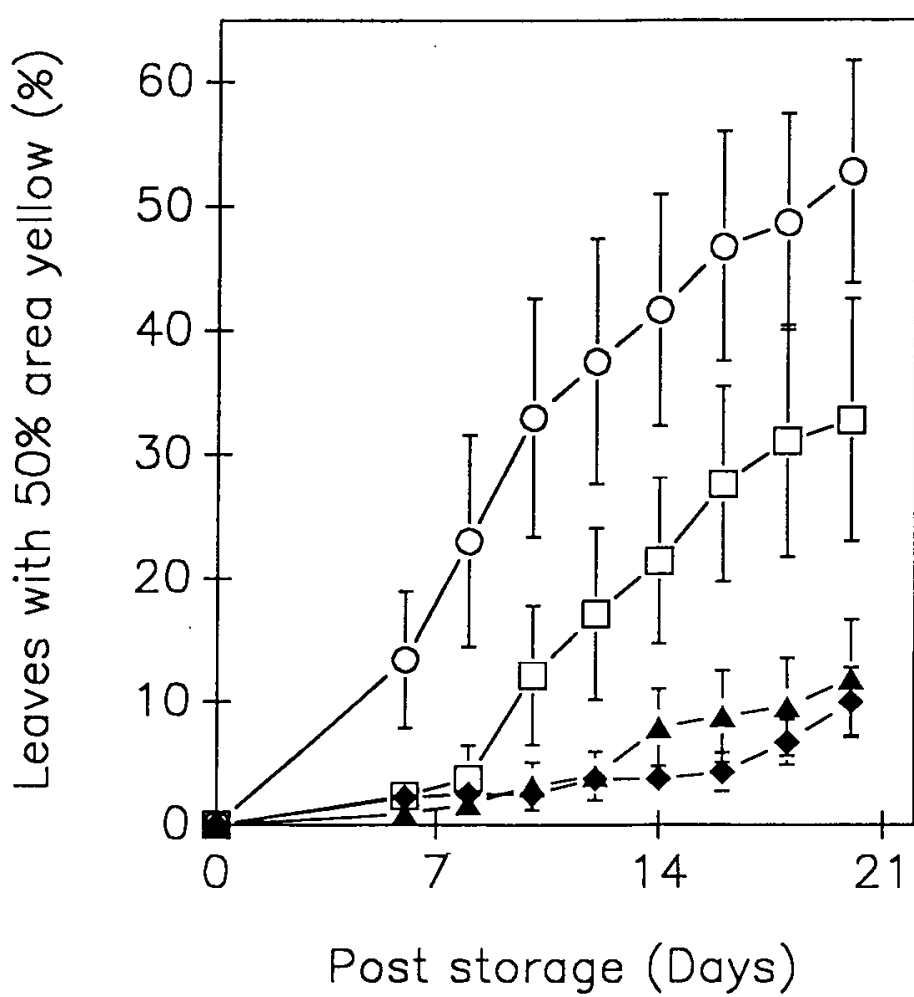

Fig. 3. Development of foliar chlorosis on Easter lily plants following 4 weeks of storage at 2C. Plants were sprayed with water $(\mathrm{O}), 500 \mathrm{mg} \cdot \operatorname{liter}^{-1}$ of $\mathrm{GA}_{3}(\boldsymbol{\Delta}), 500$ $\mathrm{mg} \cdot \mathrm{liter}{ }^{-1}$ of BA ( $\left.\square\right)$, or $500 \mathrm{mg} \cdot \mathrm{liter}^{-1}$ each of $\mathrm{GA}_{3}+\mathrm{BA}(\bullet)$ ).

delayed. In this study, changes in diffusive resistance apparently were not correlated with the development of foliar chlorosis (Fig. 1). Treatments with $\mathrm{GA}_{3}$ or $\mathrm{BA}$ at various concentrations had no effect on the aperture of the stomates despite the marked delay in the development of chlorosis (Table 1, Fig. 1).

The mechanism by which $\mathrm{GA}_{3}$ and $\mathrm{BA}$ delays senescence of excised Easter lily leaves is not known. Respiration rates of leaves treated with $\mathrm{GA}_{3}$ and/or BA declined rapidly not long after the chemical treatments (Fig. 2). The lower respiration rate of leaves indicates that carbohydrates depletion was not as rapid as in those treated with water. This, is turn, suggests that the postproduction development of foliar chlorosis in Easter lily leaves may be associated with the carbohydrate status of the leaves. Other researchers have proposed a similar theory for the cause of foliar chlorosis based on the various cultural practices followed in the greenhouse (Jiao et al., 1986, Miller, 1992; Miller et al., 1993). Application of triazole and close spacing of plants during greenhouse production results in lower leaf carbohydrates as well as a higher percentage of leaf yellowing. Time-course studies to investigate changes in respiration and in the content and composition of carbohydrates will provide a better understanding of the mechanism by which growth regulators delay the senescence of excised Easter lily leaves.

Data from excised-leaf experiments demonstrate the potential for $\mathrm{GA}_{3}$ and BA to delay leaf senescence in Easter lily. Subsequent studies were conducted on leaves on intact plants where results were consistent with those of excised leaves. Treatment of intact plants with $\mathrm{GA}_{3}, \mathrm{BA}$, or the combination of both, before the cold storage, significantly delayed post-storage development of leaf chlorosis (Fig. 3). Leaf chlorosis initiated on the lower leaves and moved upward in a progressive, but not necessarily sequential, manner. Development of leaf chlorosis on intact plants was slower than on excised leaves (Table 4, Fig. 3). All excised leaves were considered senesced 1 week after the cold storage, whereas $\approx 15 \%$ 
of the leaves on intact plants were senesced in that time. The discrepancy may be due to the differences in the carbohydrate state of the two systems. In the whole-plant system, mobilization of carbohydrates occurs between the bulb, leaves, and the flower buds. Extended longevity in the intact plants may thus be due to replenishment of carbohydrates whereas, in the excised-leaf system, the depleted carbohydrates would not be restored, resulting in more rapid senescence. At the same time, flower buds may draw from the carbohydrates source of the leaves. However, under the dark conditions of the present experiments, it is not possible to assess the effects of buds on leaf longevity. According to Mor and Halevy (1980) and Miller and Langhans (1989), irradiance plays an important role in the sink strength of flower buds. It is, thus, likely that the dark conditions used in the study altered the sink strength of the flower buds (since none of them opened fully) and consequently affected the development of foliar chlorosis. Therefore, the leaf yellowing data of the whole-plant experiment probably deviated from what one would have obtained in an interior environment. To determine the potential for use of GA, and BA in the horticultural industry, further studies on the development and longevity of the flower buds as well as on foliar chlorosis should be conducted in a postproduction environment.

\section{Literature Cited}

Anonymous. 1991 Floriculture crops. 1990 Summary. U.S. Dept. Agr. Sp Cr 6-1(91). p. 79.

Beevers, L. 1966. Effect of gibberellic acid on the senescence of leafdiscs of nasturtium, Tropaelum majus. Plant Physiol. 41:1074-1076.

Halevy, A.H. 1986. Whole plants enescence, p. 119-125. In: Y.Y Leshem, A.H. Halevy, and C. Frenkel (eds.). Developments in crop science. Elsevier, Amsterdam.

Hicklenton, P.R. 1991. GA, and benzylaminopurine delay leaf yellowing in cut Alstromeria stems. HortScience 26: 1198-1199.
Jiao, J., M.J. Tsujita, and D.P. Murr. 1986. Effects of paclobutrazol and ARest on growth, flowering, leaf carbohydrate and leaf senescence in 'Nellie White' Easter lily (Lilium longiflorum Thunb.). Scientia Hort. 30:135-141.

Leshem, Y.Y 1986. Plant senescence, p. 3-18. In: Y.Y. Leshem, A.H. Halevy, and C. Frenkel (eds.). Developments in crop science. Elsevier, Amsterdam.

Martin. C. and K.V. Thimnnn. 1972. The role of protein synthesis in the senescence of leaves. Plant Physiol. 49:64-71.

Miller. W.B. 1992. Easter and hybrid lily production. Timber Press. Portland, Ore.

Miller, W.B. 1993, Lilium longiflorum,p. 391-422. In: A. De Hertogh and M. LeNard (eds.). The physiology of flower bulbs. Elsevier, Amsterdam.

Miller, W.B., P.A. Hammer, and T.I. Kirk. 1993. Reversed greenhouse temperatures alter carbohydrate status in Lilium longiflorum Thunb. 'Nellie White'. J. Amer. Soc. Hort. Sci. 118:736-740.

Miller, W.B. and R.W. Langhans. 1989. Carbohydrate changes of Easter lilies during growth in normal and reduced irradiance environments. J. Amer. Soc. Hort. Sci. 114:310-315.

Mor, Y. and A.H. Halevy. 1980. Promotion of sink activity of developing rose shoots by light. Plant Physiol. 66:990-995.

Prince, T.A. and M.S. Cunningham. 1989. Production and storage factors influencing quality of potted Easter lilies. HortScience 24:992-994.

Prince, T.A., M.S. Cunningham, and J.S. Peary. 1987. Floral and foliar quality of potted Easter lilies after STS or phenidone application. refrigerated storage, and simulated shipment. J. Amer. Soc. Hort. Sci. 112:469-473.

Richmond, A. and A. Lang. 1957. Effect of kinetin on protein content and survival of detached Xanthium leaves. Science 125:650-651.

Thimann, K.V. 1987. Plant senescence: A proposed integration of the constituent processes. p. 1-19. Proc. X Annu. Symp. Plant Physiol. 10:1-19.

SAS Institute, 1990. SAS/STAT user's guide. 4th ed. SAS Inst., Cary, N.C.

Staby, G.L. and T.D. Erwin. 1977. The storage of Easter lilies. Florists Rev. 161:38. 